\title{
Optimization of CV.Amanda Makassar Production Planning in the Time of Covid-19 Using Multiple Goal Linear Program Model
}

\section{Optimalisasi Perencanaan Produksi CV. Amanda Makassar pada Masa Covid-19 Menggunakan Model Program Linear Tujuan Ganda}

\author{
Astri ${ }^{1, *}$, Aidawayati $\mathbf{R}^{2, *}$, Agustinus $\mathbf{R}^{3, *}$
}

\begin{abstract}
A research has been conducted on the use of multiple-goal linear program model to solve multi goals by taking the case of optimization of production planning at CV. Amanda Makassar during the Covid-19 period. In this research, four goals were formulated, that were (i) the fulfillment of the number of market demand, (ii) maximizing income, (iii) minimizing production costs, and (iv) maximizing working hours. Then for the optimal solution using LINGO 18 software. Based on the research results, the optimal production plan during the Covid-19 period resulted from the two different models for original brownies products where the results of the dual-purpose linear program model without target priority produced 16.118 original brownies and 32.400 packages from the dualpurpose linear program model with priority target with weight. For cream cheese brownies, there are 3.000 packages, 18.000 packages of sarikaya pandan brownies, 3.600 packs of choco marble brownies, pink marble brownies, tiramishu marble brownies, roasted brownies, and 1.800 packs of cappuccino marble brownies. Chocolate bananas bolen, pineapple molen, and chocolate ganache in 840 packages. Then for 15.000 packs of blueberry brownies, 960 packs of strawberry brownies, 360 packs of dry brownies, 2.400 banana cheese brownies, 300 packs of cheese bananas bolen, 600 packs of peanut butter, and 9.000 packs of pandan cake for a month. The maximum revenue obtained by the company with a multiple-purpose linear program model without target priority is Rp.628.602.000.- and the minimum production cost that the company must pay is Rp.495,048,300,Then for the multiple-purpose linear program model with target priority accompanied by a weight of Rp.4.299.480.000.- and the minimum production cost is Rp.3.394.366.000. The result shows that optimization using a multiple goal linear program model with goal priority provide optimal production which results in greater profit compared to the process (optimization) carried out by the company so far, which is only based on the number of demand.
\end{abstract}

Keywords: Multiple goal linear program, Optimization, LINGO.

\begin{abstract}
Abstrak
Telah dilakukan penelitian tentang penggunaan model program linear tujuan ganda untuk menyelesaikan multi tujuan dengan mengambil kasus optimalisasi perencanaan produksi pada CV. Amanda Makassar dalam masa Covid-19. Dalam penelitian dirumuskan empat tujuan, yaitu (i) pemenuhan jumlah permintaan pasar, (ii) memaksimalkan pendapatan, (iii) meminimalkan biaya produksi, dan (iv) memaksimalkan jam kerja. Kemudian untuk solusi optimalnya menggunakan
\end{abstract}

* Program Studi Magister Matematika, FMIPA-UNHAS

Email: ${ }^{1}$ astriaksan@gmail.com, ${ }^{2}$ aidarangkuti@yahoo.com, ${ }^{3}$ agus.ribal@gmail.com

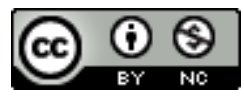

This work is licensed under a Creative Commons Attribution-NonCommercial 4.0 International 
Astri, Aidawayati R, Agustinus R

Jurnal Matematika, Statistika \& Komputasi

software LINGO 18. Berdasarkan hasil penelitian, rencana produksi optimal pada masa Covid-19 yang dihasilkan dari kedua model berbeda untuk produk brownies original dimana hasil dari model program linear tujuan ganda tanpa prioritas sasaran memproduksi brownies original sebanyak 16.118 kemasan dan 32.400 kemasan dari model program linear tujuan ganda dengan prioritas sasaran disertai bobot. Untuk produk brownies cream cheese sebanyak 3.000 kemasan, brownies sarikaya pandan 18.000 kemasan, brownies choco marble 3.600 kemasan, brownies pink marble, brownies tiramishu marble, brownies bakar, dan brownies cappucino marble sebanyak 1.800 kemasan. Pisang bolen coklat, molen nanas, dan ganache chocolate sebanyak 840 kemasan. Kemudian untuk brownies blueberry sebanyak 15.000 kemasan, brownies strawberry sebanyak 960 kemasan, brownies kering sebanyak 360 kemasan, brownies banana cheese sebanyak 2.400 kemasan, pisang bolen keju sebanyak 300 kemasan, peanut butter sebanyak 600 kemasan, dan bolu pandan sebanyak 9.000 kemasan selama sebulan. Pendapatan maksimal yang diperoleh perusahaan dengan model program linear tujuan ganda tanpa prioritas sasaran yaitu Rp.628.602.000,- dan biaya produksi minimal yang harus dikeluarkan perusahaan yaitu $\mathrm{Rp}$

495.048.300,-. Kemudian untuk model program linear tujuan ganda dengan prioritas sasaran disertai bobot yaitu Rp. 4.299.480.000,- dan biaya produksi minimal yaitu Rp.3.394.366.000,-. Hasil penelitian menunjukkan bahwa optimasi menggunakan model program linear tujuan ganda dengan prioritas sasaran disertai bobot memberikan produksi yang optimal yang berakibat pada lebih besarnya keuntungan dibanding dengan proses (optimalisasi) yang dilakukan perusahaan selama ini, yaitu hanya berdasarkan jumlah permintaan.

Kata Kunci: Program linear tujuan ganda, Optimasi, LINGO.

\section{Pendahuluan}

Optimasi adalah suatu pendekatan normatif untuk mengidentifikasikan penyelesaian terbaik dalam pengambilan keputusan dari suatu permasalahan. Penyelesaian permasalahan dalam optimasi ditujukan untuk memperoleh titik maksimal atau titik minimal dari fungsi yang dioptimalkan. Seperti permasalahan suatu perusahaan dalam menentukan jumlah produksi agar keuntungan maksimal dan biaya minimal dapat diperoleh [1].

Dalam proses produksi setiap perusahaan pasti dihadapkan pada persoalan mengoptimalkan lebih dari satu tujuan. Tujuan-tujuan dari persoalan produksi tersebut ada yang saling berkaitan dan ada juga yang saling bertentangan dimana ketika tujuan yang satu dioptimalkan akan mengakibatkan kerugian pada tujuan yang lainnya. Dalam hal ini penting untuk melakukan perencanaan yang cukup matang serta diperlukan metode penyelesaian yang bisa merangkum tujuan-tujuan tersebut sehingga diperoleh kombinasi solusi yang optimal dari faktorfaktor yang tidak bersesuaian [2].

Salah satu metode yang tepat untuk menyelesaikan persoalan tersebut adalah metode Program Linear Tujuan Ganda. Program Linear Tujuan Ganda adalah salah satu model yang dipandang sesuai digunakan untuk pemecahan masalah multi tujuan. Model Program Linear Tujuan Ganda yang sering disebut juga Model Goal Programming merupakan perluasan dari Program Linier. Secara umum Goal Programming ini digunakan untuk menyelesaikan persoalan yang memiliki tujuan ganda (atau lebih dari satu tujuan) [3].

Penelitian mengenai aplikasi model Program Linear Tujuan Ganda untuk penyelesaian masalah optimasi sudah banyak dilakukan. Diantaranya digunakan untuk pemodelan perencanaan produksi. Seperti yang dilakukan Hapsari \& Rosyidi pada tahun 2018 [4] dalam penelitiannya menggunakan model Program Linear Tujuan Ganda dengan prioritas. Pada penelitian tersebut melibatkan 3 Goal yang ingin dicapai yaitu, memaksimalkan kapasitas produksi, meminimalkan biaya bahan baku, dan memaksimalkan jam kerja mesin. Selanjutnya Anggraeni dkk., [5] yang 


\section{Astri, Aidawayati R, Agustinus R \\ Jurnal Matematika, Statistika \& Komputasi}

dalam penelitiannya memiliki 3 Goal yang ingin dicapai yaitu memaksimalkan pendapatan, meminimalkan biaya produksi, dan memaksimalkan penggunaan mesin. Penelitian tersebut menggunakan model Program Linear Tujuan Ganda dengan prioritas disertai bobot. Adeyeye \& Charles-Owaba pada tahun 2008 [6] yang dalam penelitiannya memiliki 2 Goal yang ingin dicapai yaitu meminimalkan biaya produksi dan memaksimalkan kapasitas produksi. Pada penelitan tersebut menggunakan model pre-emptive Program Linear Tujuan Ganda dengan dua struktur prioritas yang berbeda. Kemudian Puligilla Prashanth Kumar pada tahun 2019 [7] melakukan penelitian mengenai model program linear tujuan ganda untuk perencanaan produksi roti. Pada penelitiannya ada 4 Goal yang ingin dicapai yaitu memaksimalkan keuntungan, meminimalkan waktu lembur, memaksimalkan bahan baku, dan memaksimalkan kegunaan mesin. Penelitian tersebut menggunakan model Program Linear Tujuan Ganda dengan prioritas sasaran disertai bobot. Etemadi dkk., [8] melakukan penelitian menggunakan model Program Linear Tujuan Ganda dengan prioritas sassaran dosertai bobot untuk model penganggaran modal dalam industri konstruksi. Penentuan bobot tujuan menggunakan metode Fuzzy Analysis tir Hierarcy Process (FAHP)

Berbeda dengan Luiz Carlos Barbosa pada tahun 2015 [9] melakukan penelitian menggunakan model Program Linear Tujuan Ganda dengan prioritas sasaran disertai bobot dalam peningkatan efisiensi industri kimia dengan penentuan bobot menggunakan metode AHP (Analytic Hierarcy Process). Dhoruri pada tahun 2013 [10] dalam penelitiannya menggunakan model Program Linear Tujuan Ganda untuk memecahkan masalah perutean kendaraan dengan 4 Goal yang ingin dicapai yaitu memaksimalkan pemanfaatan kapasitas kendaraan, meminimalkan total waktu tunggu, meminimalkan total biaya untuk melayani pelanggan, dan memaksimalkan jumlah pelanggan yang dilayani. Pada penelitian tersebut menggunakan model Program Linear Tujuan Ganda dengan prioritas disertai bobot. Berbeda dengan Halim dkk., pada tahun 2015 [11] yang dalam penelitiannya menggunakan model Program Linear Tujuan Ganda untuk perencanaan manajemen laporan keuangan suatu Bank. Pada penelitiannya, ada enam Goal yang ingin dicapai yaitu, memaksimalkan total aset, meminimalkan hutang, memaksimalkan kekayaan ekuitas, memaksimalkan total pendapatan, memaksimalkan keuntungan, dan memaksimalkan proporsi nilai barang pada laporan keuangan. Penelitian tersebut menggunakan model Program Linear Tujuan Ganda dengan prioritas disertai bobot.

Selanjutnya, pada penelitian ini akan menggunakan model Program Linear Tujuan Ganda tanpa prioritas tujuan dan model Program Linear Tujuan Ganda dengan Prioritas disertai bobot untuk mengoptimalkan perencanaan produksi (CV. Amanda Makassar). Adapun permasalahan yang akan diteliti adalah bagaimana menentukan jumlah produksi yang optimal berdasarkan jumlah permintaan konsumen, memaksimalkan pendapatan, meminimalkan biaya produksi dan memaksimalkan jam kerja mesin. Selanjutnya, penyelesaian model Program Linear Tujuan Ganda tanpa prioritas tujuan dan model Program Linear Tujuan Ganda dengan prioritas tujuan disertai bobot akan diselesaikan dengan bantuan software LINGO 18.

\section{Metode Penelitian}

Pada tahap pertama penelitian ini, dilakukan pengumpulan beberapa data yang meliputi data produksi, data utilitas mesin, data permintaan, dan data jam kerja mesin pada masa Covid-19 bulan April tahun 2020. Kemudian tahap selanjutnya, model program linear tujuan ganda dikembangkan dan diselesaikan dengan menggunakan bantuan software LINGO 18.

\subsection{Pengumpulan data}


Astri, Aidawayati R, Agustinus R

Jurnal Matematika, Statistika \& Komputasi

Dalam pembentukan model Program Linear Tujuan Ganda dibutuhkan data yang digunakan sebagai parameter model. Tabel 1 dan 2 menunjukkan data yang dibutuhkan untuk menyelesaikan model program linear tujuan ganda. Tabel 1 menunjukkan data harga jual, biaya produksi per kemasan dari 19 jenis produk, serta jumlah permintaan setiap produk pada masa Covid-19 untuk bulan April tahun 2020, serta data jam kerja mesin produksi pada masa Covid-19 untuk bulan April tahun 2020 tercantum dalam Tabel 2.

Tabel 1. Harga Jual dan Biaya Produksi Produk (per kemasan)

\begin{tabular}{|c|c|c|c|c|}
\hline Produk & Nama Produk & $\begin{array}{l}\text { Harga Jual } \\
\text { (Rp.) }\end{array}$ & $\begin{array}{c}\text { Biaya Produksi } \\
\text { (Rp.) }\end{array}$ & $\begin{array}{c}\text { Jumlah } \\
\text { Permintaan }\end{array}$ \\
\hline$x_{1}$ & Brownies Original & 39.000 & 30.714 & 27.000 \\
\hline$x_{2}$ & $\begin{array}{c}\text { Brownies Cream } \\
\text { Cheese }\end{array}$ & 66.000 & 46.221 & 2.500 \\
\hline$x_{3}$ & $\begin{array}{c}\text { Brownies Sarikaya } \\
\text { Pandan }\end{array}$ & 45.000 & 41.692 & 15.000 \\
\hline$x_{4}$ & $\begin{array}{c}\text { Brownies Choco } \\
\text { Marble }\end{array}$ & 47.000 & 33.651 & 3.000 \\
\hline$x_{5}$ & $\begin{array}{c}\text { Brownies Pink } \\
\text { Marble }\end{array}$ & 47.000 & 33.430 & 1.500 \\
\hline$x_{6}$ & Brownies Blueberry & 47.000 & 38.746 & 12.500 \\
\hline$x_{7}$ & Brownies Tiramisu & 54.000 & 47.925 & 800 \\
\hline$x_{8}$ & $\begin{array}{c}\text { Brownies Tiramisu } \\
\text { Marble }\end{array}$ & 47.000 & 37.247 & 1.500 \\
\hline$x_{9}$ & Brownies Bakar & 42.000 & 39.268 & 1.500 \\
\hline$x_{10}$ & Brownies Kering & 36.000 & 33.133 & 300 \\
\hline$x_{11}$ & $\begin{array}{l}\text { Brownies } \\
\text { Strawberry }\end{array}$ & 45.000 & 38.579 & 750 \\
\hline$x_{12}$ & $\begin{array}{c}\text { Brownies } \\
\text { Cappucino Marble }\end{array}$ & 47.000 & 32.553 & 1.500 \\
\hline$x_{13}$ & $\begin{array}{c}\text { Brownies Banana } \\
\text { Cheese }\end{array}$ & 45.000 & 39.050 & 2000 \\
\hline$x_{14}$ & Pisang Bolen Coklat & 50.000 & 40.635 & 700 \\
\hline$x_{15}$ & Pisang Bolen Keju & 50.000 & 41.358 & 250 \\
\hline$x_{16}$ & Peanut Butter & 50.000 & 42.324 & 500 \\
\hline$x_{17}$ & Molen Nanas & 50.000 & 40.901 & 700 \\
\hline$x_{18}$ & Ganache Chocolate & 50.000 & 41.732 & 700 \\
\hline$x_{19}$ & Bolu Pandan & 30.000 & 24.840 & 7.500 \\
\hline
\end{tabular}

Sumber: CV. Amanda Makassar, 2020

Tabel 2. Jam Kerja Mesin Masa Covid-19 (per jam)

\begin{tabular}{ccccc}
\hline No & Mesin & Jumlah Mesin & $\begin{array}{c}\text { Jam Kerja Efektif } \\
\text { Per bulan (Jam) }\end{array}$ & $\begin{array}{c}\text { Kapasitas Jam Kerja } \\
\text { Mesin } \\
\text { Per bulan (jam) }\end{array}$ \\
\hline $\mathbf{1}$ & $\begin{array}{c}\text { Mesin inkject } \\
\text { print }\end{array}$ & 1 & 224 & 224 \\
\hline $\mathbf{2}$ & Steamer & 18 & 224 & 4.032 \\
\hline $\mathbf{3}$ & Oven Rotary & 2 & 224 & 448 \\
\hline $\mathbf{4}$ & Mixer besar & 2 & 224 & 448 \\
\hline $\mathbf{5}$ & Mixer kecil & 4 & 224 & 896 \\
\hline $\mathbf{6}$ & Mesin pengayak & 2 & 224 & 448 \\
\hline $\mathbf{7}$ & Kompor semawar & 36 & 224 & 8.064 \\
\hline
\end{tabular}


Astri, Aidawayati R, Agustinus R

Jurnal Matematika, Statistika \& Komputasi

\begin{tabular}{ccccc}
\hline No & Mesin & Jumlah Mesin & $\begin{array}{c}\text { Jam Kerja Efektif } \\
\text { Per bulan (Jam) }\end{array}$ & $\begin{array}{c}\text { Kapasitas Jam Kerja } \\
\text { Mesin } \\
\text { Per bulan (jam) }\end{array}$ \\
\hline $\mathbf{8}$ & Coldroom & 6 & 224 & 1.344 \\
\hline $\mathbf{9}$ & Doughsetter & 1 & 224 & 224 \\
\hline & & TOTAL & & 16.128 \\
\hline
\end{tabular}

Sumber: CV. Amanda Makassar, 2020.

\subsection{Variabel-variabel dan parameter yang digunakan}

Penelitian ini menggunakan model program linear tujuan ganda dengan variabel dan parameter yang digunakan dalam perumusan model adalah sebagai berikut:

$P_{i}:$ Prioritas ke-i

$x_{j}:$ Jumlah produk j yang diproduksi

$D$ : Pendapatan penjualan produk per bulan

$S_{j}$ : Harga jual per kemasan produk

$C_{j}$ : Biaya produksi per kemasan produk $\mathrm{j}$

$Q:$ Biaya produksi per bulan

$\mathrm{T}$ : Kapasitas jam kerja mesin per bulan

$\rho_{i}$ : Variabel yang menampung deviasi di atas sasaran

$\eta_{i}$ : Variabel yang menampung deviasi di bawah sasaran

\section{Pembentukan model matematika Program Linear Tujuan Ganda}

\subsection{Model program linear tujuan ganda tanpa prioritas sasaran}

\subsubsection{Perumusan fungsi kendala}

a. kendala sasaran untuk memenuhi jumlah permintaan produksi.

$$
\sum_{j=1}^{n} a_{i j} x_{j}+\eta_{i}-\rho_{i}=P_{i}
$$

Dengan:

$x_{j}:$ Jumlah produk $j$ yang diproduksi

$P_{i}$ : Jumlah permintaan ke- $i$

$\eta_{i}$ : Penyimpangan negative ke- $i$

$\rho_{i}$ : Penyimpangan positif ke- $i$

$$
\begin{aligned}
x_{1}+\eta_{1}-\rho_{1} & =27000 \\
x_{2}+\eta_{2}-\rho_{2} & =2500 \\
x_{3}+\eta_{3}-\rho_{3} & =15000 \\
x_{4}+\eta_{4}-\rho_{4} & =3000 \\
x_{5}+\eta_{5}-\rho_{5} & =1500 \\
x_{6}+\eta_{6}-\rho_{6} & =12500 \\
x_{7}+\eta_{7}-\rho_{7} & =800 \\
x_{8}+\eta_{8}-\rho_{8} & =1500 \\
x_{9}+\eta_{9}-\rho_{9} & =1500 \\
x_{10}+\eta_{10}-\rho_{10} & =300 \\
x_{11}+\eta_{11}-\rho_{11} & =750 \\
x_{12}+\eta_{12}-\rho_{12} & =1500 \\
x_{13}+\eta_{13}-\rho_{13} & =2000 \\
x_{14}+\eta_{14}-\rho_{14} & =700 \\
x_{15}+\eta_{15}-\rho_{15} & =250 \\
x_{16}+\eta_{16}-\rho_{16} & =500
\end{aligned}
$$


Astri, Aidawayati R, Agustinus R

Jurnal Matematika, Statistika E Komputasi

$$
\begin{aligned}
& x_{17}+\eta_{17}-\rho_{17}=700 \\
& x_{18}+\eta_{18}-\rho_{18}=700 \\
& x_{19}+\eta_{19}-\rho_{19}=7500
\end{aligned}
$$

Untuk jumlah permintaan dibatasi hingga $20 \%$ untuk produksi $x_{1}$ dan $x_{2}$, serta $10 \%$ untuk produksi $x_{3}, x_{4}, x_{5}, x_{6}, x_{7}, x_{8}, x_{9}, x_{10}, x_{11}, x_{12}, x_{13}, x_{14}, x_{15}, x_{16}, x_{17}, x_{18}$ dan $x_{19}$. Artinya penyimpangan positif $\left(\rho_{i}\right)$ dari jumlah permintaan dibatasi hingga 20\% untuk produksi $x_{1}$ dan $x_{2}$ serta $10 \%$ untuk produksi $x_{3}, x_{4}, x_{5}, x_{6}, x_{7}, x_{8}, x_{9}, x_{10}, x_{11}, x_{12}, x_{13}, x_{14}, x_{15}$ , $x_{16}, x_{17}, x_{18}$ dan $x_{19}$ terhadap permintaan itu sendiri, maka:

$\rho_{i} \leq 20 \% P_{i}, \quad \forall i=1,2$.

$\rho_{i} \leq 10 \% P_{i}, \quad \forall i=3,4, \ldots, 19$.

Sehingga diperoleh:

$\begin{array}{ll}\rho_{1} \leq 5400 & \rho_{11} \leq 150 \\ \rho_{2} \leq 500 & \rho_{12} \leq 300 \\ \rho_{3} \leq 3000 & \rho_{13} \leq 400 \\ \rho_{4} \leq 600 & \rho_{14} \leq 140 \\ \rho_{5} \leq 300 & \rho_{15} \leq 50 \\ \rho_{6} \leq 2500 & \rho_{16} \leq 100 \\ \rho_{7} \leq 160 & \rho_{17} \leq 140 \\ \rho_{8} \leq 300 & \rho_{18} \leq 140 \\ \rho_{9} \leq 300 & \rho_{19} \leq 1500 \\ \rho_{10} \leq 60 & \end{array}$

Sehingga, fungsi kendala untuk jumlah permintaan adalah sebagai berikut:

$$
\begin{gathered}
x_{1}+\eta_{1}=32400 \\
x_{2}+\eta_{2}=3000 \\
x_{3}+\eta_{3}=18000 \\
x_{4}+\eta_{4}=3600 \\
x_{5}+\eta_{5}=1800 \\
x_{6}+\eta_{6}=15000 \\
x_{7}+\eta_{7}=960 \\
x_{8}+\eta_{8}=1800 \\
x_{9}+\eta_{9}=1800 \\
x_{10}+\eta_{10}=360
\end{gathered}
$$

$$
\begin{aligned}
& x_{11}+\eta_{11}=900 \\
& x_{12}+\eta_{12}=1800 \\
& x_{13}+\eta_{13}=2400 \\
& x_{14}+\eta_{14}=840 \\
& x_{15}+\eta_{15}=300 \\
& x_{16}+\eta_{16}=600 \\
& x_{17}+\eta_{17}=840 \\
& x_{18}+\eta_{18}=840 \\
& x_{19}+\eta_{19}=9000
\end{aligned}
$$

b. kendala sasaran untuk memaksimalkan pendapatan.

$$
\begin{aligned}
& 39000 x_{1}+66000 x_{2}+45000 x_{3}+45000 x_{4}+47000 x_{5}+47000 x_{6}+47000 x_{7}+ \\
& 47000 x_{8}+42000 x_{9}+36000 x_{10}+30000 x_{11}+50000 x_{12}+50000 x_{13}+50000 x_{14}+ \\
& 50000 x_{15}+50000 x_{16}+50000 x_{17}+50000 x_{18}+50000 x_{19}+\eta_{20}-\rho_{20}=D
\end{aligned}
$$

c. kendala sasaran untuk meminimalkan biaya produksi.

$$
\begin{aligned}
& 30714 x_{1}+46221 x_{2}+41692 x_{3}+33651 x_{4}+33430 x_{5}+38746 x_{6}+47925 x_{7}+ \\
& 37247 x_{8}+39268 x_{9}+33133 x_{10}+38579 x_{11}+32553 x_{12}+39050 x_{13}+40635 x_{14}+ \\
& 41358 x_{15}+42324 x_{16}+40901 x_{17}+41732 x_{18}+24840 x_{19}+\eta_{21}-\rho_{21}=Q
\end{aligned}
$$

d. kendala sasaran untuk memaksimalkan jam kerja mesin. 
Astri, Aidawayati R, Agustinus R

\section{Jurnal Matematika, Statistika \& Komputasi}

$x_{1}+x_{2}+x_{3}+x_{4}+x_{5}+x_{6}+x_{7}+x_{8}+x_{9}+x_{10}+x_{11}+x_{12}+x_{13}+x_{14}+x_{15}+x_{16}+$
$x_{17}+x_{18}+x_{19}+\eta_{22}-\rho_{22}=16128$

\subsubsection{Perumusan fungsi tujuan}

$$
\begin{aligned}
\operatorname{Min} Z=\eta_{1}+\eta_{2}+\eta_{3}+\eta_{4}+\eta_{5}+\eta_{6}+\eta_{7}+\eta_{8}+\eta_{9}+\eta_{10}+\eta_{11}+\eta_{12} \\
+\eta_{13}+\eta_{14}+\eta_{15}+\eta_{16}+\eta_{17}+\eta_{18}+\eta_{19}+\eta_{20}+\rho_{21}+\eta_{22}+\rho_{22}
\end{aligned}
$$

\subsection{Model program linear tujuan ganda dengan prioritas sasaran disertai bobot \\ 3.2.1 Penetapan prioritas sasaran}

Pada penelitian ini penetapan tingkat prioritas sasaran diperoleh dengan meminta penetapan urutan prioritas dari pengambil keputusan di perusahaan tersebut. Dengan mempertimbangkan hasil dari penetapan tersebut peneliti menggunakannya untuk menentukan bobot prioritas dari sasaran yang ingin dicapai. Berikut ini penetapan dan pemberian bobot pada setiap prioritas asaran yang ingin dicapai.

Tabel 3. Urutan Prioritas dan Bobot

\begin{tabular}{cccc}
\hline No & Sasaran & Prioritas & Bobot \\
\hline $\mathbf{1}$ & Memenuhi jumlah permintaan & 1 & 0,5 \\
\hline $\mathbf{2}$ & Memaksimalkan pendapatan & 2 & 0,4 \\
\hline $\mathbf{3}$ & Meminimalkan biaya produksi & 3 & 0,3 \\
\hline $\mathbf{4}$ & Memaksimalkan jam kerja mesin & 4 & 0,2 \\
\hline
\end{tabular}

Sumber: CV. Amanda Makassar, 2020

Dengan mengasumsikan P1 sebagai sasaran dengan prioritas pertama, P2 sebagai sasaran dengan prioritas kedua, P3 sebagai sasaran dengan prioritas ketiga, dan P4 sebagai sasaran dengan prioritas keempat.

\subsubsection{Model matematika}

Pada pemodelan sebelumnya pembuatan perencanaan produksi tanpa memperhatikan prioritas telah diuraikan tentang kendala-kendala sasaran yang ingin dicapai perusahaan. Pada model kali ini perbedaannya hanya terletak pada fungsi tujuan saja dengan kendala yang masih sama. Fungsi tujuan dengan prioritas dan penambahan bobot yang berbeda pada setiap prioritasnya sebagai berikut.

Kendala sasaran:

$$
\begin{aligned}
x_{1}+\eta_{1} & =32400 \\
x_{2}+\eta_{2} & =3000 \\
x_{3}+\eta_{3} & =18000 \\
x_{4}+\eta_{4} & =3600 \\
x_{5}+\eta_{5} & =1800 \\
x_{6}+\eta_{6} & =15000 \\
x_{7}+\eta_{7} & =960 \\
x_{8}+\eta_{8} & =1800 \\
x_{9}+\eta_{9} & =1800 \\
x_{10}+\eta_{10} & =360
\end{aligned}
$$

$$
\begin{aligned}
& x_{11}+\eta_{11}=900 \\
& x_{12}+\eta_{12}=1800 \\
& x_{13}+\eta_{13}=2400 \\
& x_{14}+\eta_{14}=840 \\
& x_{15}+\eta_{15}=300 \\
& x_{16}+\eta_{16}=600 \\
& x_{17}+\eta_{17}=840 \\
& x_{18}+\eta_{18}=840 \\
& x_{19}+\eta_{19}=9000
\end{aligned}
$$


Astri, Aidawayati R, Agustinus R

Jurnal Matematika, Statistika \& Komputasi

$$
\begin{aligned}
& 39000 x_{1}+66000 x_{2}+45000 x_{3}+45000 x_{4}+47000 x_{5}+47000 x_{6}+47000 x_{7}+ \\
& 47000 x_{8}+42000 x_{9}+36000 x_{10}+30000 x_{11}+50000 x_{12}+50000 x_{13}+50000 x_{14}+ \\
& 50000 x_{15}+50000 x_{16}+50000 x_{17}+50000 x_{18}+50000 x_{19}+\eta_{20}-\rho_{20}=D \\
& 30714 x_{1}+46221 x_{2}+41692 x_{3}+33651 x_{4}+33430 x_{5}+38746 x_{6}+47925 x_{7}+ \\
& 37247 x_{8}+39268 x_{9}+33133 x_{10}+38579 x_{11}+32553 x_{12}+39050 x_{13}+40635 x_{14}+ \\
& 41358 x_{15}+42324 x_{16}+40901 x_{17}+41732 x_{18}+24840 x_{19}+\eta_{21}-\rho_{21}=Q \\
& x_{1}+x_{2}+x_{3}+x_{4}+x_{5}+x_{6}+x_{7}+x_{8}+x_{9}+x_{10}+x_{11}+x_{12}+x_{13}+x_{14}+x_{15}+x_{16}+ \\
& x_{17}+x_{18}+x_{19}+\eta_{22}-\rho_{22}=16128
\end{aligned}
$$

Maka persamaan fungsi tujuan dengan pemberian prioritas beserta bobot didalamnya menjadi:

$$
\begin{aligned}
\operatorname{Min} Z=0,5 P 1 & \left(\eta_{1}+\eta_{2}+\eta_{3}+\eta_{4}+\eta_{5}+\eta_{6}+\eta_{7}+\eta_{8}+\eta_{9}+\eta_{10}+\eta_{11}+\eta_{12}\right. \\
& \left.+\eta_{13}+\eta_{14}+\eta_{15}+\eta_{16}+\eta_{17}+\eta_{18}+\eta_{19}\right)+0,4 P 2\left(\eta_{20}\right)+0.3 P 3\left(\rho_{21}\right) \\
& +0,2 P 4\left(\eta_{22}+\rho_{22}\right)
\end{aligned}
$$

\begin{tabular}{|c|c|c|c|c|}
\hline No & Kendala & Sasaran & Hasil & Keterangan \\
\hline \multirow[t]{19}{*}{1} & \multirow{19}{*}{$\begin{array}{l}\text { Memenuhi jumlah } \\
\text { permintaan produk }\end{array}$} & 32.400 & 16.118 & Tidak tercapai \\
\hline & & 3.000 & 3000 & Tercapai \\
\hline & & 18.000 & 18000 & Tercapai \\
\hline & & 3.600 & 3600 & Tercapai \\
\hline & & 1.800 & 1800 & Tercapai \\
\hline & & 15.000 & 15000 & Tercapai \\
\hline & & 960 & 960 & Tercapai \\
\hline & & 1.800 & 1800 & Tercapai \\
\hline & & 1.800 & 1800 & Tercapai \\
\hline & & 360 & 360 & Tercapai \\
\hline & & 900 & 900 & Tercapai \\
\hline & & 1.800 & 1800 & Tercapai \\
\hline & & 2.400 & 2.400 & Tercapai \\
\hline & & 840 & 840 & Tercapai \\
\hline & & 300 & 300 & Tercapai \\
\hline & & 600 & 600 & Tercapai \\
\hline & & 840 & 840 & Tercapai \\
\hline & & 840 & 840 & Tercapai \\
\hline & & 9.000 & 9.000 & Tercapai \\
\hline 2 & $\begin{array}{l}\text { Memaksimalkan } \\
\text { pendapatan }\end{array}$ & $Q$ & 628.602 .000 & Tercapai \\
\hline 3 & $\begin{array}{l}\text { Meminimlakan biaya } \\
\text { produksi }\end{array}$ & $D$ & 495.048 .300 & Tercapai \\
\hline 5 & Memaksimalkan jam kerja & 16.128 & 0.00 & Tercapai \\
\hline
\end{tabular}

\section{Hasil dan Pembahasan}

Pada penelitian ini, penyelesaian permasalahan yang telah diformulasikan dalam bentuk model program linear tujuan ganda diperoleh solusi yang optimal dengan bantuan aplikasi LINGO 18.

\subsection{Penyelesaian optimal model program linear tujuan ganda tanpa prioritas sasaran}

Hasil optimasi dapat dilihat pada Tabel 4. Model diselesaikan dengan menggunakan software LINGO 18.

Tabel 4. Nilai variabel yang optimal berdasarkan hasil output LINGO 18 pada masa Covid-19 
Astri, Aidawayati R, Agustinus R

\section{Jurnal Matematika, Statistika \& Komputasi}

$\frac{\text { mesin }}{\text { Sumber: Data diolah, } 2020 .}$

Dari Tabel 4. dapat dilihat bahwa usaha untuk mencapai sasaran penentuan jumlah produk tidak dapat tercapai oleh semua jenis produk. Dari output yang di dapat, model menyarankan untuk memproduksi produk $x_{1}$ sebanyak 16.118 kemasan, $x_{2}$ sebanyak 3.000 kemasan, $x_{3}$ sebanyak 18.000 kemasan, $x_{5}, x_{8}, x_{9}$, dan $x_{12}$ sebanyak 1.800 kemasan. $x_{14}, x_{17}$, dan $x_{18}$ sebanyak 840 kemasan. Adapun untuk produk $x_{4}$ sebanyak 3.600 kemasan, $x_{6}$ sebanyak 15.000 kemasan, $x_{10}$ sebanyak 360 kemasan, $x_{11}$ sebanyak 900 kemasan, $x_{13}$ sebanyak 2.400 kemasan, $x_{15}$ sebanyak 300 kemasan, $x_{16}$ sebanyak 824 kemasan dan $x_{19}$ sebanyak 9.000 kemasan. Dari Tabel 4. juga didapatkan kombinasi solusi optimal yaitu:

a. Sasaran untuk memenuhi jumlah permintaan produk terpenuhi, hanya untuk produk $x_{2}, x_{3}, x_{4}, x_{5}, x_{6}, x_{7}, x_{8}, x_{9}, x_{10}, x_{11}, x_{12}, x_{13}, x_{14}, x_{15}, x_{16}, x_{17}, x_{18} \quad$ dan $x_{19}$. Sedangkan untuk $x_{1}$ tidak terpenuhi karena jumlah penyimpangan negatifnya $\left(\eta_{1}\right)$ adalah 16282.00

b. Sasaran memaksimalkan pendapatan penjualan terpenuhi dengan memperoleh pendapatan sebesar Rp. 628.602.000,-. Ini terlihat dari nilai $\eta_{20}$ terhadap total harga jual adalah 0.00 .

c. Sasaran meminimalkan biaya produksi terpenuhi yaitu Rp. 495.048.300,-. Ini terlihat dari nilai $\eta_{21}$ terhadap total biaya produksi adalah 0.00

d. Sasaran memaksimalkan jam kerja mesin tercapai karena tidak terdapat nilai penyimpangan negative dari penggunaan jam kerja mesin $\left(\eta_{22}\right)$.

\subsection{Penyelesaian optimal model program linear tujuan ganda dengan prioritas sasaran disertai bobot}

Hasil optimasi dapat dilihat pada Tabel 5. Model diselesaikan dengan menggunakan software LINGO 18.

Tabel 5. Nilai variabel yang optimal berdasarkan hasil output LINGO 18 pada masa Covid-19

\begin{tabular}{|c|c|c|c|c|}
\hline No & Kendala & Sasaran & Hasil & Keterangan \\
\hline \multirow[t]{17}{*}{1} & Memenuhi jumlah & 32.400 & 32.400 & Tercapai \\
\hline & permintaan produk & 3.000 & 3000 & Tercapai \\
\hline & & 18.000 & 18.000 & Tercapai \\
\hline & & 3.600 & 3600 & Tercapai \\
\hline & & 1.800 & 1800 & Tercapai \\
\hline & & 15.000 & 15000 & Tercapai \\
\hline & & 960 & 960 & Tercapai \\
\hline & & 1.800 & 1800 & Tercapai \\
\hline & & 1.800 & 1800 & Tercapai \\
\hline & & 360 & 360 & Tercapai \\
\hline & & 900 & 900 & Tercapai \\
\hline & & 1.800 & 1800 & Tercapai \\
\hline & & 2.400 & 2.400 & Tercapai \\
\hline & & 840 & 840 & Tercapai \\
\hline & & 300 & 300 & Tercapai \\
\hline & & 600 & 600 & Tercapai \\
\hline & & 840 & 840 & Tercapai \\
\hline
\end{tabular}


Astri, Aidawayati R, Agustinus R Jurnal Matematika, Statistika \& Komputasi

\begin{tabular}{ccccc}
\hline & & 840 & 840 & Tercapai \\
\cline { 2 - 5 } & & 9.000 & 9.000 & Tercapai \\
\hline $\mathbf{2}$ & $\begin{array}{c}\text { Memaksimalkan } \\
\text { pendapatan }\end{array}$ & $Q$ & 4.299 .480 .000 & Tercapai \\
\hline $\mathbf{3}$ & $\begin{array}{c}\text { Meminimlakan biaya } \\
\text { produksi }\end{array}$ & $D$ & 3.394 .366 .000 & Tercapai \\
\hline $\mathbf{4}$ & Memaksimalkan jam kerja \\
mesin & 16.128 & 0.00 & Tercapai \\
\hline
\end{tabular}

Sumber: Data diolah, 2020.

Dari Tabel 5. dapat dilihat bahwa usaha untuk mencapai sasaran penentuan jumlah produk tercapai oleh semua jenis produk. Dari output yang di dapat, model menyarankan untuk memproduksi produk $x_{1}$ sebanyak 32.400 kemasan, $x_{2}$ sebanyak 3.000 kemasan, $x_{3}$ sebanyak 18.000 kemasan, $x_{5}, x_{8}, x_{9}$, dan $x_{12}$ sebanyak 1.800 kemasan. $x_{14}, x_{17}$, dan $x_{18}$ sebanyak 840 kemasan. Adapun untuk produk $x_{4}$ sebanyak 3.600 kemasan, $x_{6}$ sebanyak 15.000 kemasan, $x_{10}$ sebanyak 360 kemasan, $x_{11}$ sebanyak 900 kemasan, $x_{13}$ sebanyak 2.400 kemasan, $x_{15}$ sebanyak 300 kemasan, $x_{16}$ sebanyak 824 kemasan dan $x_{19}$ sebanyak 9.000 kemasan. Dari tabel di atas juga didapatkan kombinasi solusi optimal yaitu:

a. Sasaran untuk memenuhi jumlah permintaan produk terpenuhi, untuk semua produk $x_{1}, x_{2}, x_{3}, x_{4}, x_{5}, x_{6}, x_{7}, x_{8}, x_{9}, x_{10}, x_{11}, x_{12}, x_{13}, x_{14}, x_{15}, x_{16}, x_{17}, x_{18}$ dan $x_{19}$.

b. Sasaran memaksimalkan pendapatan penjualan terpenuhi dengan memperoleh pendapatan sebesar Rp. 4.229.480.000,-. Ini terlihat dari nilai $\eta_{20}$ terhadap total harga jual adalah 0.00 .

c. Sasaran meminimalkan biaya produksi terpenuhi yaitu Rp. 3.394.366.000,-. Ini terlihat dari nilai $\eta_{21}$ terhadap total biaya produksi adalah 0.00

d. Sasaran memaksimalkan jam kerja mesin tercapai karena tidak terdapat nilai penyimpangan negative dari penggunaan jam kerja mesin $\left(\eta_{22}\right)$.

\section{Analisis Sensitivitas}

Analisis sensitivitas merupakan analisis yang dilakukan pada hasil optimasi suatun kasus. Penggunaan analisis sensitivitas bertujuan untuk mengetahui sejauh mana perubahan yang diperbolehkan pada hasil optimasi yang diperoleh. Informasi tentang hasil analisis sensitivitas pada model program linear tujuan ganda dikerjakan dengan bantuan software LINGO 18

\subsection{Analisis Sensitivitas model program linear tujuan ganda tanpa prioritas sasaran}

Hasil optimal dari model program linear tujuan ganda dengan bantuan LINGO 18 diperoleh sasaran memaksimalkan pendapatan sebesar Rp.628.602.000dalam satu bulan. Berdasarakan analisis sensitivitas pendapaatn tersebut masih dapat ditingkatkan sebesar Rp. 628.602.000 untuk satu bulan yang mana keoptimalan pendapatan tersebut masih dapat dipertahankan sehingga pendapatan yang dapat dicari ada pada kisaran nilai A yaitu $628.602 .000 \leq A \leq 628.602 .000+628.602 .000$. Untuk sasaran meminimalkan biaya produksi sebesar Rp. 495.048.300 untuk satu bulan. Berdasarakn analisis sensitivitas biaya produksi tersebut masih dapat ditingkatkan sebesar Rp. 495.048.300 untuk satu bulan yang mana keoptimalan biaya produksi masih dapat dipertahankan sehinggan biaya produksi dapat dicari pada kisaran nilai B yaitu 495.048.300 $\leq$ B $\leq 495.048 .300+495.048 .300$. 


\section{Astri, Aidawayati R, Agustinus R Jurnal Matematika, Statistika \& Komputasi}

Untuk sasaran memaksimalkan jam kerja diperoleh hasil optimal yaitu jam 16.118 dalam satu bulan. Berdasarkan hasil analisis sensitivitas jam kerja tersebut masih dapat ditingkatkan sebesar 16.282 jam untuk satu bulan dan dapat ditirunkan sebesar 16.118 untuk satu bulan yang mana keoptimalan dari jam kerja masih dapat dipertahankan sehingga jam kerja maksimal yang dapat dicari ada pada kisaran nilai $\mathrm{C}$ yaitu $16.128-16.128 \leq \mathrm{C} \leq 16.128+16.282$.

Output LINGO 18 menunjukkan bahwa sasaran pemenuhan target produksi $x_{1} 32.400$ kemasan masih dapat ditingkatkan sebanyak tidak terhingga dan dapat dikurangi sebanyak 32.400 kemasan. Untuk produksi $x_{5}, x_{8}, x_{9}$, dan $x_{12}$ dapat ditingkatkan sebanyak tidak terhingga dan dapat dikurangi sebanyak 1.800 kemasan. Untuk produksi $x_{14}, x_{17}$, dan $x_{18}$ dapat ditingkatkan sebanyak tidak terhingga dan dapat dikurangi sebanyak 840 kemasan. Untuk produksi $x_{2}, x_{3}, x_{4}, x_{6}, x_{7}, x_{10}, x_{11}, x_{13}, x_{15}, x_{16}$, dan $x_{19}$ masih dapat ditingkatkan sebanyak tidak terhingga dan dapat dikurangi masing-masing sebanyak 3.000, 18.000, 3.600, 15.000, 960, 360, 900, 2.400, 300, 600, dan 9.000 kemasan.

Hasil dari analisis sensitivitas diperoleh bahwa harga produk dapat ditingkatkan hampir setengah dari harga optimal produk. Untuk perubahan harga setiap produk, berdasarkan analisis sensitivitas dengan bantuan LINGO 18 menunjukkan harga untuk produk $x_{1}$ dapat ditingkatkan sebesar Rp.3.714 dan dapat diturunkan sebanyak Rp.15.949,68 yang mana keoptimalan harga tersebut masih dapat dipertahankan sehingga harga yang dapat dicari pada kisaran nilai $x_{1}$ yaitu $39.000-15.949,68 \leq x_{1} \leq 39.000+3.714$. untuk harga produk $x_{2}$ dapat ditingkatkan sebesar Rp.38.131,86 dan dapat diturunkan sebesar tak hingga. Untuk harga produk $x_{3}$ dapat ditingkatkan sebesar Rp.21.650,52 dan dapat diturunkan sebesar tak hingga. Untuk harga produk $x_{4}$ dapat dinaikkan sebesar Rp.26.581,85 dan dapat diturunkan sebesar tak hingga. Selanjutnya untuk harga produk $x_{5}$ dapat ditingkatkan sebesar Rp.27.887,58 dan dapat diturunkan sebanyak tak hingga. Kemudian untuk harga produk $x_{6}, x_{7}, x_{8}, x_{9}, x_{10}$, dan $x_{11}$ dapat ditingkatkan sebesar Rp.21.560,75., Rp.41.329,81., Rp.31.243,02., Rp.33.019,63., Rp.28826,49., dan Rp.33163,95 dan dapat diturunkan sebanyak tak hingga. Kemudian untuk harga produk $x_{12}, x_{13}, x_{14}, x_{15}, x_{16}, x_{17}, x_{18}$, dan $x_{19}$ dapat ditingkatkan sebesar Rp.27.116,62., Rp.32.327,99., Rp.35.021,33., Rp.36.106,91., Rp.36.706,09., Rp.35.255,17., Rp.35.985,68., dan Rp.14.336,30. Dan dapat diturunkan sebanyak tak hingga.

\subsection{Analisis Sensitivitas model program linear tujuan ganda dengan prioritas sasaran disertai bobot}

Sama seperti analisis sensitivitas pada model program linear tujuan ganda tanpa prioritas sasaran pada masa Covid-19, Output LINGO 18 menunjukkan bahwa hasil optimal dari model program linear tujuan ganda dengan bantuan LINGO 18 diperoleh sasaran memaksimalkan pendapatan sebesar Rp. 4.299.480.000 dalam satu bulan. Berdasarakan analisis sensitivitas pendapaatn tersebut masih dapat ditingkatkan sebesar Rp. 4.299.480.000 untuk satu bulan yang mana keoptimalan pendapatan tersebut masih dapat dipertahankan sehingga pendapatan yang dapat dicari ada pada kisaran nilai A 4.299.480.000 $\leq \mathrm{A} \leq 4.299 .480 .000+4.299 .480 .000$. Untuk sasaran meminimalkan biaya produksi sebesar Rp. 3.394.366.000 untuk satu bulan. Berdasarakn analisis sensitivitas biaya produksi tersebut masih dapat ditingkatkan sebesar Rp. 3.394.366.000 untuk satu bulan yang mana keoptimalan biaya produksi masih dapat dipertahankan sehinggan biaya produksi dapat dicari pada kisaran nilai B yaitu 3.394.366.000 $\leq$ $\mathrm{B} \leq 3.394 .366 .000+3.394 .366 .000$. 


\section{Astri, Aidawayati R, Agustinus R Jurnal Matematika, Statistika \& Komputasi}

Untuk sasaran memaksimalkan jam kerja diperoleh hasil optimal yaitu 16.118 jam dalam satu bulan. Berdasarkan hasil analisis sensitivitas jam kerja tersebut masih dapat ditingkatkan sebesar 80.112 jam untuk satu bulan dan dapat yang mana keoptimalan dari jam kerja masih dapat dipertahankan sehingga jam kerja maksimal yang dapat dicari ada pada kisaran nilai C yaitu $16.128 \leq \mathrm{C} \leq 16.128+80.122$.

Sama seperti analisis sensitivitas pada model Goal Programming tanpa prioritas sasaran pada masa Covid-19, Output LINGO 18 menunjukkan bahwa sasaran pemenuhan target produksi $x_{1} 32.400$ kemasan masih dapat ditingkatkan sebanyak tidak terhingga dan dapat dikurangi sebanyak 32.400 kemasan. Untuk produksi $x_{5}, x_{8}, x_{9}$, dan $x_{12}$ dapat ditingkatkan sebanyak tidak terhingga dan dapat dikurangi sebanyak 1.800 kemasan. Untuk produksi $x_{14}, x_{17}$, dan $x_{18}$ dapat ditingkatkan sebanyak tidak terhingga dan dapat dikurangi sebanyak 840 kemasan. Untuk produksi $x_{2}, x_{3}, x_{4}, x_{6}, x_{7}, x_{10}, x_{11}, x_{13}, x_{15}, x_{16}$, dan $x_{19}$ masih dapat ditingkatkan sebanyak tidak terhingga dan dapat dikurangi masing-masing sebanyak 3.000, 18.000, 3.600, 15.000, 960, 360, 900, 2.400, 300, 600, dan 9.000 kemasan.

Untuk analisis sensitivitas perubahan harga setiap produk diperoleh hasil bahwa perubahan harga dari setiap produk sebelum Covid-19 dan pada masa Covid-19 untuk model program linear tujuan ganda dengan prioritas sasaran tidak mengalami peningkatan dan penurunan harga yang signifikan pada masa Covid-19.

\section{Kesimpulan}

Dari penggunaan kedua model program linear tujuan ganda tanpa prioritas sasaran dan dengan prioritas sasaran disertai bobot diperoleh hasil yang berbeda untuk jumlah permintaan yang optimal pada produk $x_{1}$. Pendapatan maksimal yang diperoleh perusahaan dengan model Program Linear Tujuan Ganda tanpa prioritas sasaran yaitu Rp. 628.602.000,- dan biaya produksi minimal yang harus dikeluarkan perusahaan yaitu Rp. 495.048.300,-. Kemudian untuk model Program Linear Tujuan Ganda dengan prioritas sasaran disertai bobot yaitu Rp. 4.299.480.000,- dan biaya produksi minimal yaitu Rp.394.366.000,--

Dari hasil kedua model tersebut, jika kita asumsikan bahwa keuntungan dapat diperoleh dari pengurangan antara pendapatan dan biaya produksi, maka hasil dari model program linear tujuan ganda dengan prioritas sasaran disertai bobot lebih optimal daripada model program linear tujuan ganda tanpa prioritas karena keuntungan yang diperoleh lebih besar.

Dalam penelitian ini diketahui bahwa kombinasi produk yang diperoleh dari model program linear tujuan ganda yang telah dibentuk berbeda dengan yang diterapkan perusahaan selama ini. Untuk itu, agar perusahaan dapat mencapai keuntungan yang maksimal, maka penulis menyarankan untuk memproduksi produk sesuai dengan solusi optimal yang diperoleh dengan model program linear tujuan ganda.

\section{Daftar Pustaka}

[1] Damanik, Elikson, dkk. (2013). Penerapan Metode Goal Programming Untuk Mengoptimalkan

[1] Produksi The (Studi Kasus: PT Pekebunan Nusantara IV - Pabrik Teh Bandung), Jurnal Saintia Matematika Vol. 1, No. 2, pp. 117 - 128.

[2] Taha, Hamdy A. (2007). Operation Research: An Introduction. New Jarsey : Person Education, Inc.

[3] Taha, Hamdy A. (1996). Riset Operasi: Suatu Pengantar. Jakarta: Binarupa Aksara 
Astri, Aidawayati R, Agustinus R

\section{Jurnal Matematika, Statistika \& Komputasi}

[4] Hapsari, S. N. \& Rosyidi, C. N., (2018). A Goal Programming Optimization Model for the Allocation of Liquid Steel Production. IOP Conf. Series:Materials Science and Engineering.

[5] Anggraeni, Wiwik, dkk., (2015). Production Planning Optimization Using Goal Programming Method in Habibah Busana. Journal of Advan Management Sciense, Volume. 3, No. 4.

[6] Adeyeye, A. D. \& Charles-Owaba, O. E., (2008). Goal Programming Model for Production Planning in a Toothpaste Factory. South African Journal of Industrial Engineering, Volume 19(2), pp. 197-209.

[7] Kumar, Puligilla Prashanth. (2019). Goal Programming Through Bakery Production, Internasional Journal of Scientific \& Technology Research, Volume 8.

[8] Etemadi, S, dkk., (2018). A Goal Programming Capital Budgeting Model Under Uncertainty in Construction Industry. Science Iranica E. 25(2). pp 841-851.

[9] Barbosa, Luis Carlos. \& Luiz Flavio Autran Monteiro Gomes., (2015). Assessment of Efficiency and Sustainability in a Chemical Industry using a Goal Programming and AHP. Procedia Computer Science, 55 . pp 165-174

[10] Dhoruri, Atmini, dkk., (2013). A Goal Programming Approach to Solve Vehicle Routing Problem Using Lingo. Proceeding of IICMA.

[11] Halim, Bushra Abdul, dkk., (2015). Bank Financial Statement Management Using a Goal Programming Model. Procedia- Social and Behavioral Science, 211. pp 498-504. 